\title{
Tall fescue and chicory for increased summer forage production
}

\author{
M.D. ROLLO ${ }^{1}$, G.W. SHEATH ${ }^{1}$, M.W.A. SLAY ${ }^{2}$, T.L. KNIGHT ${ }^{3}$, T.G. JUDD ${ }^{4}$ \\ and N.A. THOMSON ${ }^{5}$ \\ ${ }^{1}$ AgResearch, Ruakura Research Centre, Private Bag 3123, Hamilton \\ ${ }^{2}$ AgResearch, Poukawa Research Centre, PO Box 8144, Havelock North \\ ${ }^{3}$ AgResearch, Canterbury Agriculture and Science Centre, PO Box 60, Lincoln \\ ${ }^{4}$ Inaha Rd, RD11, Hawera \\ ${ }^{5}$ Dairying Research Corporation, Private Bag 3123, Hamilton
}

\begin{abstract}
Production of summer forage is an important consideration in environments prone to extremes of heat or moisture stress. Tall fescue (Festuca arundinacea) and chicory (Cichorum intybus) are two forage species with the potential to overcome the production shortfalls of perennial ryegrass (Lolium perenne) in such environments. Trials from three New Zealand regions prone to summer drought (Taranaki, Hawke's Bay and Canterbury) were used to compare production of tall fescue and chicory with production from resident ryegrass. Consistent production advantages from tall fescue and chicory were evident in the two years after establishment. Potential production advantages can disappear in subsequent years when summer moisture levels are very high or very low, or temperatures extremely high. Moderate moisture levels in summer, indicated by moderate ryegrass production, gave the biggest relative summer production advantages to tall fescue.
\end{abstract}

Keywords: chicory, dryland, forage production, ryegrass, tall fescue

\section{Introduction}

Production of sufficient summer forage can be a problem in drought-prone areas of New Zealand. Forage production in New Zealand has traditionally been based around perennial ryegrass (Lolium perenne) and white clover (Trifolium repens.) pastures. The shallow root system of ryegrass makes it susceptible to moisture stress which can significantly affect production. Attack by insect pests such as grass grub and Argentine stem weevil may coincide with drought stress to further reduce summer ryegrass production.

Many other forage species are available to New Zealand pastoral farmers. Charlton \& Belgrave (1992) reviewed the range of pasture species available then in New Zealand, including tall fescue (Festuca arundinacea) and chicory (Cichorum intybus), and rated attributes such as drought tolerance, summer growth and persistence.
This paper compares production of tall fescue and chicory with resident ryegrass production in areas prone to summer moisture and heat stress. Three separate pasture species trials, in Taranaki, Hawke's Bay and Canterbury, are described. Analysis is presented on a case study basis, reporting differences in summer and annual production. Implications for animal performance in sheep systems are discussed.

\section{Tall fescue}

Tall fescue is grown to increase summer forage production. The importance of tall fescue in New Zealand pastoral farming has been widely discussed, along with drawbacks (Brock 1983; Easton et al. 1994; Milne et al. 1997). Reported problems include establishment, fertility, grazing management requirements and persistence (Easton et al. 1994). Tall fescue is a deeper-rooted perennial grass from the same family (Festucoidae) as ryegrass, noted for tolerance to moisture stress and pests (Kain et al. 1979). Rhizome development has been indicated as a factor in the spread and performance of tall fescue (Brock 1997). It does not start until 2 years after autumn sowing and can be reduced by inappropriate grazing management.

\section{Chicory}

The tap-rooted herb chicory is another species capable of providing summer forage in conditions where ryegrass production is compromised. Rumball (1986) described the development of cv. Grasslands Puna, a New Zealandbred cultivar. Chicory also suffers problems relating to establishment, grazing management and persistence ( $\mathrm{Li}$ et al. 1997). Effective use of chicory appears to be a compromise between total production and feed quality (Li et al. 1994). The main advantage of Chicory is high growth rates in late spring and summer (Hare et al. 1987), although it is effectively dormant in winter with little production. It has been widely adopted in New Zealand as a specialist feed (Li et al. 1997).

\section{Site and trial descriptions}

Production of summer forage using ryegrass based pastures is limited in the trial areas by high water deficits (Table 1). Summer is defined as the period December to 
March (inclusive) when growth is usually limited by lack of moisture.

Table 1 Long-term average summer climate.

\begin{tabular}{lcccc}
\hline & $\begin{array}{c}\text { Soil temp } \\
\left({ }^{\circ} \mathrm{C}\right)\end{array}$ & $\begin{array}{c}\text { Rainfall } \\
(\mathrm{mm})\end{array}$ & $\begin{array}{c}\text { aPET } \\
(\mathrm{mm})\end{array}$ & $\begin{array}{c}\text { bWater deficit } \\
(\mathrm{mm})\end{array}$ \\
\hline Poukawa $^{1,2}$ & 18.1 & 244 & $435^{3}$ & 191 \\
TARS & $17.0^{4}$ & $290^{4}$ & $451^{5}$ & 161 \\
Winchmore & 15.6 & 256 & 491 & 235 \\
\hline a & potential evapotranspiration (PET) $=$ rainfall - pan evaporation \\
& $\times 0.8$ \\
b & water deficit = rainfall - PET \\
1 & Poukawa long term weather data from Havelock North weather \\
& station \\
2 & Poukawa and Winchmore means 1950-1980 \\
3 & $\begin{array}{l}\text { Poukawa pan evaporation 1962-1980 } \\
4\end{array}$ \\
5 & Data from Patea meteorological station \\
& TARS pan evaporation data from Manaia demonstration farm \\
\hline
\end{tabular}

\section{Winchmore (Canterbury)}

Winchmore research station is located in midCanterbury, an area considered dryland by New Zealand standards. The major agricultural land use on the Canterbury Plains is grazed pasture based on perennial ryegrass and white clover. Annual rainfall is low (longterm average $753 \mathrm{~mm}$ ) with droughts occurring mainly in summer and autumn. Low summer rainfall and high moisture losses (Table 1) typify the water deficit problems of a Canterbury summer. Low winter temperatures can hinder recovery from prolonged droughts (Rickard \& Radcliffe 1976).

Two separate trials compared production of resident ryegrass with tall fescue (Trial 1) and chicory (Trial 2). Trial 1 was designed to measure pasture species response to drought stress and 3 irrigation levels were specified (nil, or at $10 \%$ and $20 \%$ soil moisture by weight). Cultivars reported are Super Nui (resident ryegrass) and Grasslands Roa (tall fescue). Trial 2 was designed to measure the survival and production of drought hardy species in a dryland environment. Cultivars used were Grasslands Pacific (resident ryegrass) and Grasslands Puna (chicory).

All grasses were sown with a clover mixture and each species replicated 3 times. Fertility was maintained with superphosphate (grasses) and nitrogen (chicory). Each species was managed according to the prevailing recommendations.

\section{Taranaki Agricultural Research Station (Taranaki)}

Located at the Taranaki Agricultural Research Station (TARS) in south Taranaki on a soil of above average fertility, this environment is characterised by warm dry summers and frequent grass grub damage. Data was from a trial comparing production from Grasslands Roa tall fescue with production from an old ryegrass-white clover pasture from 1982 to 1988 (Judd et al. 1990). Clover was sown with the tall fescue treatment. The trial was rotationally grazed by dairy cows and production was measured with a trim technique.

\section{Poukawa (Hawke's Bay)}

Poukawa Research Station consists of easy contour paddocks on a medium-high natural fertility soil type. Extreme summer temperatures can combine with high soil moisture deficits to reduce summer forage production. The trial reported evaluated production from several alternative species and two ryegrasses. Tall fescue (Au Triumph) and chicory (Grasslands Puna) were sown as pure species, with nitrogen used to maintain fertility. Tall fescue was sown in autumn 1990 and chicory in spring 1989. Sheep were used for grazing and 5 years' production is reported.

\section{Results and discussion}

\section{Trial climatic conditions}

All three trials were characterised by warm, dry summers. Poukawa summers during the trial period were hot (average $10 \mathrm{~cm}$ soil temperature $21.1^{\circ} \mathrm{C}$ ) and dry (average rainfall $212 \mathrm{~mm}$ ). Mild average soil temperatures $\left(18.8^{\circ} \mathrm{C}\right)$ and higher rainfall $(310 \mathrm{~mm})$ in the summer of 1992-93 favoured ryegrass production at Poukawa (Table 4). The summer of 1994-95 was particularly hot (average $100 \mathrm{~mm}$ soil temperature $23.2^{\circ} \mathrm{C}$ ) and dry (rainfall $143 \mathrm{~mm}$ ) resulting in decreased production from all three species (Table 4 ).

TARS had warm (average $100 \mathrm{~mm}$ soil temperature $15.6^{\circ} \mathrm{C}$ ) summers and rainfall averaged $354 \mathrm{~mm}$ in the trial period.

Winchmore was the driest site with summer rainfall averaging $197 \mathrm{~mm}$ during the trial period. Summer soil temperatures averaged $15.9^{\circ} \mathrm{C}$ (Trial 1) and $16.1^{\circ} \mathrm{C}$ (Trial 2).

\section{Annual production}

Average annual production at the trial sites (Table 2) appears to reflect local climatic conditions. Ryegrass production ranged from an annual average of $8020 \mathrm{~kg}$ DM at Winchmore (dryland) to $14690 \mathrm{~kg}$ DM at TARS. This pattern is consistent with the level of meteorological water deficit at the sites (Table 1). Tall fescue production followed the same pattern, exceeding average annual ryegrass production at each site (Table 2).

Tall fescue's annual production advantage was greatest at the sites with moderate water deficits. The greatest annual tall fescue production advantages were at Taranaki (2290 kg DM) and the moderate irrigation treatment at Winchmore (2000 kg DM). The hot and dry conditions at Poukawa restricted the average annual 
advantage of tall fescue to $570 \mathrm{~kg}$ DM. Ryegrass produced close to potential in the fully irrigated Winchmore treatment where the tall fescue advantage was reduced to $250 \mathrm{~kg} \mathrm{DM}$.

Chicory production averaged $9600 \mathrm{~kg} \mathrm{DM}$ at Poukawa and $9050 \mathrm{~kg}$ DM for the two years it was grown at Winchmore. Most chicory production occurred in spring and summer, with little winter production recorded.

Table 2 Average annual total yield (kg DM) for each species treatment.

\begin{tabular}{lccc}
\hline & Ryegrass & Tall fescue & Chicory \\
\hline Poukawa & 9860 & 10430 & 9590 \\
TARS & 14690 & 16980 & \\
Winchmore $^{1}$ & 8020 & 9030 & 9050 \\
Winchmore $^{2}$ & 8310 & 10310 & \\
Winchmore $^{3}$ & 14020 & 14270 & \\
\hline 1 & & & \\
2 & Dryland & & \\
3 & Fully irrigated & & \\
\hline
\end{tabular}

\section{Summer production - early advantage after establishment}

The two years after establishment showed an increase in average summer production of tall fescue at each site. This early advantage had reduced or disappeared in the following years at all sites (Table 3). The relative advantage was greatest at the sites with moderate levels of ryegrass production, Poukawa and the moderately irrigated Winchmore treatment (Table 3). Summer chicory production at Poukawa and Winchmore followed a similar pattern.

Table 3 Average summer production during trial lifetime. Ryegrass production ( $\mathrm{kg} \mathrm{DM}$ ) and tall fescue production relative to ryegrass (base level of 100 ).

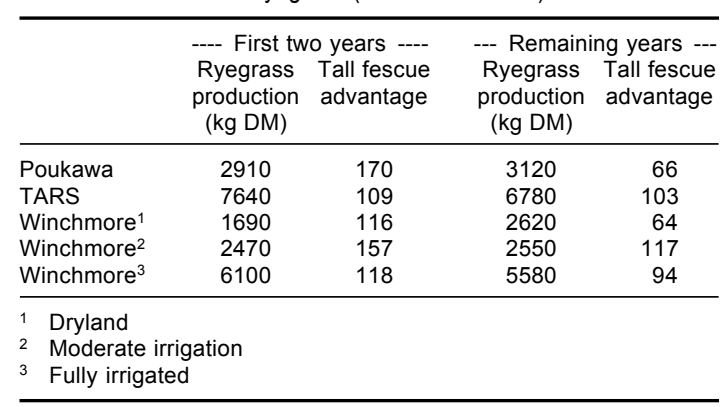

Ryegrass production at Poukawa was favoured by increasing summer rainfall in the second and third years after establishment (Table 4). Good summer rainfall $(310 \mathrm{~mm})$ and mild soil temperatures (average $18.8^{\circ} \mathrm{C}$ ) in the summer of 1992-93 resulted in the maximum ryegrass production $(6260 \mathrm{~kg} \mathrm{DM})$ and the lowest level of tall fescue production relative to ryegrass $(55 \%)$ during the trial period (Table 4).

Table 4 Poukawa: summer climate, ryegrass production ( $\mathrm{kg} \mathrm{DM})$, tall fescue and chicory production relative to ryegrass (base level of 100).

\begin{tabular}{lccccc}
\hline & $90 / 91$ & $91 / 92$ & $92 / 93$ & $93 / 94$ & $94 / 95$ \\
\hline Avg. soil temp $\left({ }^{\circ} \mathrm{C}\right)$ & 22.5 & 19.8 & 18.8 & 21.0 & 23.2 \\
Rainfall $(\mathrm{mm})$ & 192 & 240 & 310 & 176 & 143 \\
Ryegrass $(\mathrm{kg} \mathrm{DM})$ & 1200 & 4610 & 6260 & 2220 & 863 \\
Tall fescue & 308 & 134 & 55 & 87 & 90 \\
Chicory & 357 & 117 & 61 & 117 & 168 \\
\hline
\end{tabular}

Tall fescue production at TARS and Winchmore showed a similar trend of early advantage with a decline after the first 2 years (Table 3 ).

Trends in chicory production at Poukawa were similar to tall fescue production. During the first 2 years average summer chicory production exceeded ryegrass production by $1940 \mathrm{~kg}$ DM. Chicory production averaged $530 \mathrm{~kg}$ DM less than ryegrass for the remaining 3 years of the trial. Summer production of chicory at Winchmore exceeded ryegrass production by $500 \mathrm{~kg}$ $\mathrm{DM}$ and $300 \mathrm{~kg}$ DM in the two summers it was grown. Ryegrass production in the Winchmore chicory trial averaged $3200 \mathrm{~kg}$ DM in both years.

This pattern of an early production advantage followed by a decline was also found for spring production of tall fescue and chicory, and winter production of tall fescue.

\section{Response to irrigation}

Moderate irrigation gave the greatest annual tall fescue production advantage at Winchmore (Table 2). All species were compromised in the dryland treatment and response to full irrigation was greater for annual production of ryegrass $(75 \%)$ than tall fescue $(58 \%)$. The ryegrass response is consistent with McBride's (1994) average annual yield increases in Canterbury of up to $80 \%$ when compared with non-irrigated pasture.

Summer production of tall fescue relative to ryegrass at Winchmore was greatest for the moderate irrigation treatment at $157 \%$ or $1400 \mathrm{~kg} \mathrm{DM}$ (Table 3).

\section{Implications for animal performance}

Animal performance can benefit from the higher quality of tall fescue pastures. This is mainly owing to increased clover content (T.J. Fraser, D.R. Smith, pers. comm.), particularly in summer. Archer \& Robinson (1988) showed that the presence of white clover was the most 
important factor influencing animal production with higher digestibility and nitrogen content than companion grasses especially in summer and autumn.

Dissection data from Winchmore and TARS showed an increased clover content in the tall fescue pastures. Tall fescue was sown as a pure sward at Poukawa. White clover content (by weight) at Winchmore averaged $12.3 \%$ for ryegrass ( $9 \%$ dryland, $14 \%$ fully irrigated) and $17.5 \%$ for tall fescue $(16 \%$ dryland, $18 \%$ fully irrigated). At TARS, white clover content averaged more by weight in tall fescue pastures $(20 \%)$ than in the ryegrass pastures $(15 \%)$.

Winter production of tall fescue compared favourably with ryegrass production at all sites. Average production advantages to tall fescue for the period May to July were $310 \mathrm{~kg}$ DM (Winchmore) and $150 \mathrm{~kg}$ DM (TARS). At Poukawa there was a slight $(80 \mathrm{~kg} \mathrm{DM})$ decrease in winter production. A tall fescue based system should compare favourably with a ryegrass system for setting animals up for spring production, e.g., preparing sheep for an early lactation in August.

Korte \& Rhodes (1993) assessed the economics of drought tolerant species for cattle finishing in the Hawke's Bay. They highlighted the negative impact of establishment costs and persistence on profitability. Their modelling showed the benefits of alternative pastures to be largest in good years owing to improved forage quality and least in bad (drought) years.

\section{Conclusions}

Tall fescue and chicory showed a consistent production advantage in the first two years after establishment when compared with resident ryegrass production. Potential initial production advantages can disappear in subsequent years especially when summer soil moisture levels are very high or very low. In situations of high summer soil moisture, tall fescue produces well, although the ryegrass response will be greater. At very low summer soil moisture levels there is little production from any species, emphasising that water ultimately limits production from any species. The relative summer production advantage of tall fescue was greatest in conditions of moderate soil moisture.

\section{ACKNOWLEDGEMENTS}

Thanks to D.G. McCall for assistance with the preparation of this manuscript. This work was funded by a grant from the New Zealand Foundation for Science and Technology. We acknowledge Bruce Allan and Dick Martin who were in charge of the Winchmore programme. The assistance of Jenny Moore (sorting and entering data) and field staff who collected data over many years Kushla Moffett (Poukawa) and Gerald Hayes (Winchmore) is gratefully acknowledged.

\section{REFERENCES}

Archer, K.A.; Robinson, G.G. 1988. Agronomic potential of native grass species of the Northern Tablelands of New South Wales. II Nutritive value. Australian journal of agricultural research 39: 425436.

Brock, J.L. 1983. 'Grasslands Roa' tall fescue : a review. Proceedings of the New Zealand Grassland Association 44: 74-80.

Brock, J.L.; Albrecht, K.A.; Hume, D.E. 1997. Stolons and rhizomes in tall fescue under grazing. Proceedings of the New Zealand Grassland Association 59: 93-98.

Charlton, J.F.L.; Belgrave, B.R. 1992. The range and use of pasture species in New Zealand and their use in different environments. Proceedings of the New Zealand Grassland Association 54: 99-104.

Easton, H.S.; Lee, C.K.; Fitzgerald, R.D. 1994. Tall fescue in Australia and New Zealand. New Zealand journal of agricultural research 37: 405-417.

Hare, M.D.; Rolston, M.P.; Crush, J.R.; Fraser, T.J. 1987. Puna Chicory - a perennial herb for New Zealand pasture. Proceedings Agronomy Society of New Zealand 17: 45-49.

Judd, T.G.; Thomson, N.A.; McCallum, D.A. 1990. Pasture management and pasture species for improved dry matter production in south Taranaki. Proceedings of the New Zealand Grassland Association 51: 109-112.

Kain, W.M.; Slay, M.W.; Atkinson, D.S. 1979. Evaluation of grass grub plant interactions of grasses sown with and without white clover in Central Hawke's Bay. Proceedings of Weed and Pest Conference 32: 86-91.

Korte, C.J.; Rhodes, A.P. 1993. Economics of droughttolerant pastures for cattle finishing on Hawke's Bay and Wairarapa hill country farms. Proceedings of the New Zealand Grassland Association 55: 45-49.

Li, G.; Kemp, P.D.; Hodgson, J. 1994. Control of reproductive growth in Puna chicory by grazing management. Proceedings of the New Zealand Grassland Association 56: 213-217.

Li, G.D.; Kemp, P.D.; Hodgson, J. 1997. Herbage production and persistence of Puna chicory (Chichorium intybus L.) under grazing management over 4 years. New Zealand journal of agricultural research 40: 51-56.

McBride, S.D. 1994. Pasture yield responses to irrigation in Canterbury. Proceedings of the New Zealand Grassland Association 56: 165-168. 
Milne, G.D.; Shaw, R.; Powell, R.; Pirie, B.; Pirie, J. 1997. Tall fescue use on dairy farms. Proceedings of the New Zealand Grassland Association 59: 163167.

Rickard, D.S.; Radcliffe, J.E. 1976. Seasonal distribution of pasture production in New Zealand XII Winchmore, Canterbury Plains dryland and irrigated. New Zealand journal of experimental agriculture 4: 329335.

Rumball, W. 1986. 'Grasslands Puna' chicory (Chichorium intybus L.). New Zealand journal of experimental agriculture 14: 105-107. 